\title{
Recent enhancement of the immunity in AIDS and other immunocompromised patients by hyperforin an antibiotic from Hypericum perforatum L. (in vitro model) part I
}

\author{
Ilia Brondz ${ }^{1,2^{*}}$, Anton Brondz ${ }^{3}$ \\ ${ }^{1}$ Department of Biology, University of Oslo, Oslo, Norway; ${ }^{*}$ Corresponding Author: ilia.brondz@bio.uio.no \\ ${ }^{2}$ R \& D Department, Jupiter Ltd., Ski, Norway; ilia.brondz@gmail.com \\ ${ }^{3}$ Department of Chemistry, Norwegian University of Science and Technology, Trondheim, Norway; $\underline{\text { abrondz@gmail.com }}$
}

Received 16 July 2012; revised 17 August 2012; accepted 26 August 2012

\begin{abstract}
Today, Hypericum perforatum L. is probably one of the best-characterized medicinal plants, and hyperforin is its best-characterized constituent. Extracts from $\boldsymbol{H}$. perforatum are widely used as antidepressants; however, less attention has been given to other properties of hyperforin, such as antitumor, fungicidal, antiviral and antibacterial action, or its possible use as a substance with immunomodulation properties. The present study summarizes results that describe the influence of hyperforin as an immunomodulation agent on phagocytosis and the breakdown of Escherichia coli by human polymorphonuclear neutrophils (PMNs). Hyperforin at $1-100 \mu \mathrm{g} / \mathrm{mL}$ concentrations was found to have a major influence on phagocytosis and the breakdown of E. coli by PMNs in vitro. A $100 \mu \mathrm{g} / \mathrm{mL}$ solution of hyperforin increased the uptake of non-opsonized $E$. coli almost 50 -fold, and the uptake of IgG-opsonized E. coli more than threefold; on the other hand, the uptake of serum-opsonized bacteria was reduced to approximately $60 \%$ of that of the control. Hyperforin seems to bind to both PMNs and E. coli and acts like an opsonin. The elimination of remnants of IgG-opsonized $E$. coli from the PMNs was stimulated by hyperforin, while the elimination of remnants from non-opso nized and serum-opsonized material was unaffected by the drug. Hyperforin exhibited clear immunomodulation ability as a phagocytosis-stimulating agent. Hyperforin is probably inactive against human immunodeficiency virus (HIV) and most Gram-negative bacteria. However, it can protect acquired immunodeficiency syndro-
\end{abstract}

me (AIDS) patients and other immunocompromised patients by its antibacterial activity against Gram-positive bacteria and by enhancement of phagocytosis of Gram-positive and Gramnegative bacteria; some Gram-negative bacteria, such as Neisseria, are sensitive to hyperforin. Hyperforin has the ability to penetrate the blood-brain barrier (BBB) and blood-testis barrier (BTB) and is a valuable antibacterial agent against meningitis and gonorrhea. These properties of hyperforin are important for an antibiotic with immunomodulation activity in the struggle against the growing mortality in AIDS patients as a result of opportunistic bacteria, as recently shown by Bekondi et al. (2006, Int. J. Infect. Dis. 10, 387-395). It could also help to combat primary and opportunistic pathogens associated with meningitis in adults' relation to HIV serostatus.

Keywords: Immunomodulation; Phagocytosis; AIDS; E. coli; Hyperforin; Hypericum perforatum L.

\section{INTRODUCTION}

In ancient Greece, Hypericum perforatum was used for its antidepressant properties as well as for treatment of skin injuries, burns and neuralgia. The presence of antibacterial substances in the plant genus Hypericum has been known in the scientific literature for more than 70 years. In 1943, Osborn [1] demonstrated that extracts of a number of Hypericum species were active against Staphylococcus aureus but inactive against Escherichia coli. In the case of $H$. perforatum, Neuwald and Hagenstrøm [2] found in 1954 petroleum ether and acetone extracts of the flowering herb and the dry fruits to be 
active against $S$. aureus but not against Salmonella typhi and E. coli. Gaind and Ganjoo [3] confirmed their results in 1959 and obtained evidence for the presence of two compounds exhibiting activity against a number of Grampositive microorganisms. Such extracts have been used as food and perfume preservatives [4], and also to treat infections [5].

The first interest in hyperforin was as an antibiotic extracted and purified from the plant $H$. perforatum $\mathrm{L}$. The crude alcohol extract was patented in the former USSR under the name "Novoimanin" [6,7]. Novoimanin is a mixture of different extractible substances and thus has a broad spectrum of physiological properties; however, it cannot be used intravenously or by other means of injection. The main interest of the research in the former USSR was the antibacterial activity of the extracts' main component, hyperforin $[5,8]$, and its antifungal activity [9].

In 1979, research on the antibiotic hyperforin and other substances in $H$. perforatum was conducted in Norway [10], and several corrections were made [11-14] to existing publications, including the detection of antibacterial activity of hyperforin against Gram-negative bacteria such as Neisseria [10]. A study of the antimicrobial spectrum was reported in [10]. Development of antibioticresistant microorganisms has increased the interest in hyperforin as an antibacterial agent [15].

In 1982 [13] and 1983 [14], the Norwegian team of Brondz et al. published articles related to the relative and absolute stereochemistry of hyperforin. In publication [13], the relative stereochemistry of hyperforin was determined using the X-ray crystallographic structure of hyperforin 3,5-dinitrobenzoate ester. The stereochemistry of a drug molecule is very important for its pharmacological effectiveness and toxic properties and for the possibility of synthesizing the drug. In publication [14], Brondz et al. proposed the absolute configuration (absolute stereochemistry) of hyperforin based on a study of the single-crystal X-ray analysis of the structure of the $p$-bromobenzoate ester of hyperforin (Figure 1). From this, it appears that hyperforin has the stereochemistry $(1 R, 5 S, 6 R, 7 S)$-4-hydroxy-6-methyl-1,3,7-tris (3-methyl-2-butenyl)-5-(2-methyl-1-oxopropyl)-6-(4-methyl-3 -pentenyl) bicycle [3.3.1] non-3-ene-2,9-dione, as publish ed in the Merck Index [16]. Hydroperoxycadiforin was isolated from $H$. perforatum by Rücker et al. [17], and the structure was elucidated by extensive one- and two-dimensional NMR spectroscopy. The structure of hydroperoxycadiforin bears a hyperforin and a sesquiterpene moiety. The original hyperforin and hyperforin moiety in hydroperoxycadiforin share the same nomenclature and configuration of the chiral carbons. By this independent determination of hydroperoxycadiforin stereochemistry, the stereochemistry of hyperforin was supported.

Hyperforin's antibacterial spectrum includes a number

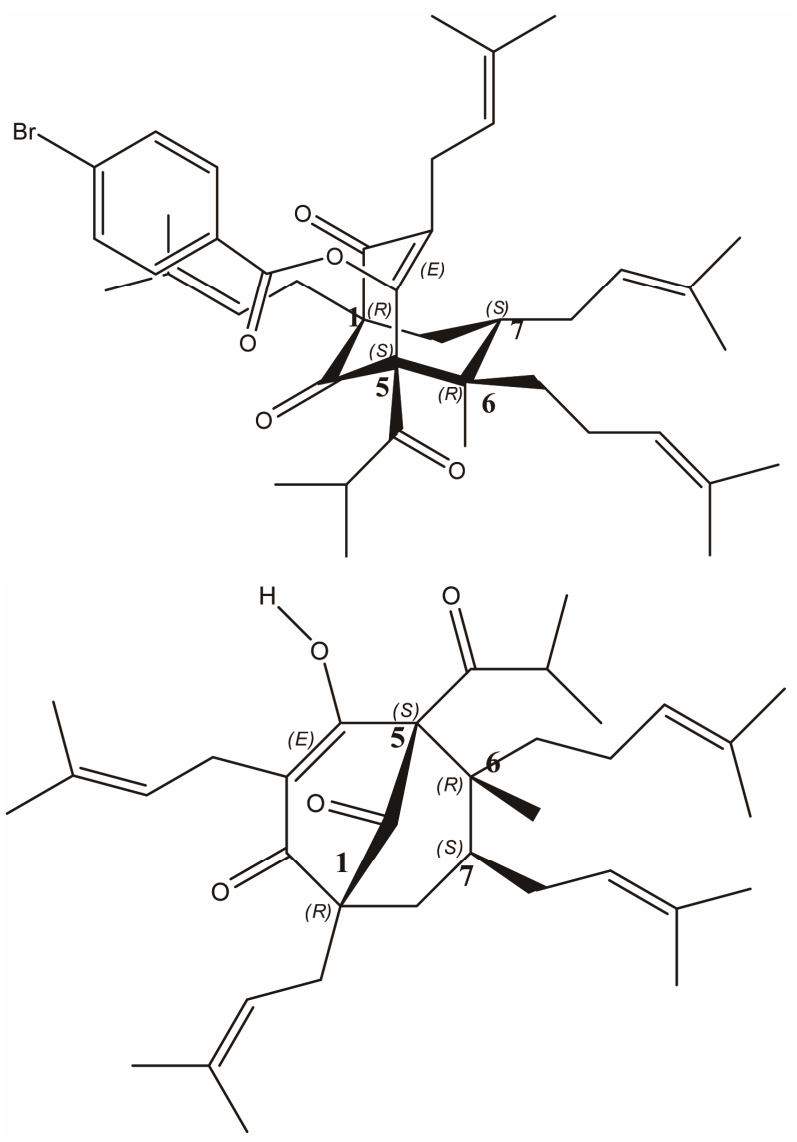

Figure 1. The upper trail is $p$-Bromobenzoate ester of hyperforin [14] and the lower trail is hyperforin as it depicted in [16] (1R,5S6R7S)-4-Hydroxy-6-methyl-1,3,7-tris(3-methyl-2-butenyl )-5-(2-methyl-1-oxopropyl)-6-(4-methyl-3-pentenyl)bicycle[3. 3.1]non-3-ene-2,9-dione.

of Gram-positive microorganisms, but it is inactive against Gram-negative Enterobacteriaceae such as E. coli [10] and other Gram-negative bacteria. However, it is active against Neisseria [10] and is able to penetrate the blood-brain barrier (BBB) and blood-testis barrier (BTB). It is very important in cases of meningitis and gonorrhea. The present publication summarizes results that describe the influence of hyperforin on phagocytosis and the breakdown of the Gram-negative bacterium E. coli by human polymorphonuclear neutrophils (PMNs). Hyperforin at $1-100 \mu \mathrm{g} / \mathrm{mL}$ was found to have a major influence on phagocytosis and the breakdown of $E$. coli by PMNs in vitro. A $100 \mu \mathrm{g} / \mathrm{mL}$ solution of hyperforin increased the uptake of non-opsonized $E$. coli almost 50-fold, and the uptake of IgG-opsonized E. coli more than threefold; on the other hand, the uptake of serum-opsonized bacteria was reduced to approximately $60 \%$ of that of the control. Hyperforin seemed to bind to both PMNs and E. coli and acted like an opsonin. The elimination of IgG-opsonized E. coli from the PMNs was stimulated by hyperforin, while the elimination of remnants from non-opsonized bacteria was unaffected by the 
drug.

PMNs are important contributors to host defense reactions against bacterial infections. Inadequate host defense may result in serious infections, as is sometimes seen in immunocompromised hosts. It is especially important in the case of immunocompromised persons such as those who have been infected with human immunodeficiency virus (HIV), diabetic persons or those intoxicated by chemicals [18]. Hyperforin is a very powerful antibiotic against the Coccaceae family of bacteria, including Streptococcus pneumoniae, Neisseria gonorrhoeae and N. meningitidis, which contain both antibiotic-sensitive and multiple-antibiotic-resistant species [10]. Hyperforin has the ability to pass through the BBB and the BTB. There is a registered increased incidence of meningococcal disease in HIV-infected individuals associated with higher fatality ratios [19-24]. Sexually transmitted infections such as gonorrhea also have a high incidence among HIV-infected individuals. In such patients, infection should be treated not only with traditional chemotherapy but also, ideally, with antimicrobial drugs stimulating host defense reactions, such as phagocytosis.

In this paper, a study of the influence of hyperforin on the in vitro phagocytosis of $E$. coli by human PMNs is presented. E. coli was chosen because of its resistance to the antibacterial effects of hyperforin, as a model in which the effect of hyperforin's antibiotic action was eliminated and the concurrent action of serum and hyperforin as opsonins was established.

\section{MATERIALS AND METHODS}

\subsection{Human Polymorphonuclear Granulocytes (PMNs)}

Blood and serum from healthy donors were purchased from the Blood Bank. Human serum was used heat-untreated, providing an intact complement. Leighton tubes with human PMNs were purchased from Jupiter Ltd. (Ski, Norway). The PMNs were prepared according to the technique of Bøyum [25-27] using Polymorphprep ${ }^{\mathrm{TM}}$ from Axis-Shield PoC AS (Oslo, Norway). The recovered granulocytes were washed once in Krebs Ringer Phosphate buffer enriched with $10 \mathrm{nM}$ glucose and resuspended in Krebs Ringer Phosphate buffer enriched with $10 \mathrm{nM}$ glucose to a final concentration of $2.5 \times 10^{6}$ cells $/ \mathrm{mL}$. Aliquots of $1 \mathrm{~mL}$ of these suspensions, which were of at least $95 \%$ purity, were added to Leighton tubes $(16 \times 125 \mathrm{~mm}$, Bellco Glass Inc., Vineland, NJ, USA). The tubes were placed in a horizontal position at $37^{\circ} \mathrm{C}$ for $60 \mathrm{~min}$. A monolayer of neutrophils with approximately 5000 cells per square $\mathrm{mm}$ was established during that time.

\subsection{Preincubation of the Bacteria}

Serum-sensitive E. coli (ATCC 11775) grown under standardized conditions to a density of $10^{9} \mathrm{CFU} / \mathrm{mL}$, in a medium prepared according to Benacerraf et al. [28], were supplied with $1 \mathrm{mCi}$ of ${ }^{32} \mathrm{P}$-labeled orthophosphate from BRITATOM (Mumbai, India) per $200 \mathrm{~mL}$ of medium. Bacteria were incubated in a gyratory shaker for $200 \mathrm{~min}$ at $37^{\circ} \mathrm{C}$. The bacteria were washed twice in icecold Krebs Ringer Phosphate buffer enriched with $10 \mathrm{nM}$ glucose to stop growth and remove surplus radioactivity, and a stock suspension of $10^{10} \mathrm{CFU} / \mathrm{mL}$ Krebs Ringer Phosphate buffer enriched with $10 \mathrm{nM}$ glucose was prepared. This suspension was kept on ice until further use within 30 min (but not longer). At the start of opsonization or phagocytosis, the bacteria were diluted to $10^{9}$ $\mathrm{CFU} / \mathrm{mL}$.

\subsection{IgG}

Antibodies were raised in rabbits by intravenous injection of a heat-treated suspension of serum-sensitive $E$. coli twice weekly for 12 weeks. The IgG fraction of the serum was purified by batch adsorption on DEAESephadex A-50 (Pharmacia, Sweden) and then precipitated with ammonium sulfate. The precipitate was dissolved in phosphate-buffered saline and desalted on an Amersham Biosciences PD-10 desalting column (Amersham Biosciences AB, Uppsala, Sweden). The final preparation agglutinated the bacteria at a titer of 256 . When a 10-fold dilution of the preparation was tested by gel diffusion against sheep anti-rabbit whole serum and sheep anti-rabbit IgG, only one precipitation line was found. This indicated that most of the protein in the preparation was IgG.

\subsection{IgG Opsonization of Bacteria}

Opsonization of $E$. coli with rabbit anti-E. coli $\operatorname{IgG}$ was carried out with a suspension of $10^{9}$ bacteria $/ \mathrm{mL}$ in a water bath shaker at $37^{\circ} \mathrm{C}$ for $30 \mathrm{~min}$. A fourfold dilution of the agglutinating titer of IgG was used. The bacteria were then washed in ice-cold Krebs Ringer Phosphate buffer enriched with $10 \mathrm{nM}$ glucose, resuspended to $10^{9}$ bacteria $/ \mathrm{mL}$ and prewarmed at $37^{\circ} \mathrm{C}$ for $5 \mathrm{~min}$ before phagocytosis.

\subsection{Opsonization of Bacteria with Serum}

Opsonization with serum was performed by the addition of serum to a final concentration of $10 \%$ and $10^{9}$ bacteria $/ \mathrm{mL}$. The serum used was not heat-inactivated. This suspension was prewarmed in a water bath at $37^{\circ} \mathrm{C}$ for $5 \mathrm{~min}$ before phagocytosis was started.

\subsection{Phagocytosis}

At the end of the preincubation period, the PMN monolayer was washed once with Krebs Ringer Phosphate buffer enriched with $10 \mathrm{nM}$ glucose $\left(37^{\circ} \mathrm{C}\right)$, and the up- 
take was started by adding $1 \mathrm{~mL}$ aliquots of the suspension of non-opsonized or opsonized E. coli, with or without hyperforin, as indicated below. The tubes were placed in a horizontal position during the uptake phase, which was stopped after $30 \mathrm{~min}$ by washing the PMNs four times with ice-cold Krebs Ringer Phosphate buffer enriched with $10 \mathrm{nM}$ glucose. For the study of the elimination of bacterial breakdown products from the PMNs, the cells were washed with prewarmed Krebs Ringer Phosphate buffer enriched with $10 \mathrm{nM}$ glucose $\left(37^{\circ} \mathrm{C}\right)$ and incubated for another $60 \mathrm{~min}$ at $37^{\circ} \mathrm{C}$. The elimination was then stopped by washing the cells with ice-cold Krebs Ringer Phosphate buffer enriched with $10 \mathrm{nM}$ glucose.

\subsection{Hyperforin}

Hyperforin was extracted from dried material of $H$. perforatum purchased from Norsk Medisinaldepot (NMD, Oslo, Norway) and purified as previously described $[10,13,14]$. A stock solution of $50 \mathrm{mg} / \mathrm{mL}$ was stored at $4{ }^{\circ} \mathrm{C}$ in $96 \%$ ethanol, sheltered from light. Immediately before use, the solution was diluted to a final concentration of 1,10 or $100 \mu \mathrm{g} / \mathrm{mL}$ in physiological solution. The drug, bacteria, opsonins and PMNs were combined in the following ways:

1) The bacteria were preincubated with hyperforin for $30 \mathrm{~min}$ at $37^{\circ} \mathrm{C}$ and then washed twice with ice-cold Krebs Ringer Phosphate buffer enriched with $10 \mathrm{nM}$ glucose before the start of phagocytosis. In the case of IgG-opsonized bacteria, opsonization and preincubation were performed simultaneously. Phagocytosis took place in the absence of hyperforin;

2) The PMN monolayer was preincubated with the drug for $30 \mathrm{~min}$ before the start of phagocytosis, which took place in the absence of hyperforin;

3) The PMNs were preincubated with hyperforin for $30 \mathrm{~min}$ and the bacteria for $5 \mathrm{~min}$, after which the uptake was performed in the presence of hyperforin.

\subsection{Quantitation of Cell Protein and Radioactivity}

After the final washing, the tubes were dried, and 1 $\mathrm{mL}$ of Lowry's alkaline copper solution was added to the PMNs to dissolve the cells overnight at room temperature. Cell protein was then determined according to the method of Oyama et al. [29], and radioactivity was counted in a Beckman LS 3801 Scintillation Counter liquid scintillation counter at $4^{\circ} \mathrm{C}$ (Lab Extreme, Inc., Kent City, MI, USA). The uptake of E. coli by the PMNs was expressed as counts per mg cell protein per min. The elimination was expressed in the same way by subtracting the values found after elimination from those found at the end of the uptake period. The medium covering the
PMNs during the elimination phase was also assayed for radioactivity before and after centrifugation at 10,000 $\mathrm{g}$ for $10 \mathrm{~min}$, to discriminate between particle-bound and soluble radioactivity. Detachment of PMNs from the monolayer could thus be assessed.

\subsection{Calculations and Statistics}

All of the experiments were performed with 3 - 5 parallel runs and repeated at least five times. The uptake of $E$. coli in PMNs, as influenced by hyperforin, was expressed as a percentage of the control. The controls were parallel experiments, but without the antibiotic hyperforin. The elimination was expressed as the percentage of ingested radioactivity that was released from the PMNs during the elimination period both after control uptake and after uptake influenced by hyperforin. Student's t test was used for statistical analysis and a $\mathrm{P}$ value $<0.05$ was considered statistically significant.

\section{RESULTS AND DISCUSSION}

\subsection{Influence of Opsonization on Phagocytosis}

When phagocytosis took place in the presence of $10 \%$ serum, the uptake of $E$. coli increased by a factor of 23.0 \pm 3.0 (mean $\pm \mathrm{SD}, \mathrm{n}=41$ ), compared with uptake of non-opsonized bacteria.

Correspondingly, opsonization by anti-E. coli IgG resulted in an enhancement of the uptake by $35.8 \pm 15.7$ (mean $\pm \mathrm{SD}, \mathrm{n}=35$ ).

\subsection{Preincubation of $E$. coli with Hyperforin}

The uptake of $E$. coli pretreated with hyperforin is outlined in Table 1. With non-opsonized bacteria, a stimulation of uptake was observed with $100 \mu \mathrm{g} / \mathrm{mL}$ of hyperforin, whereas the uptake of serum-opsonized and IgGopsonized $E$. coli was inhibited by 10 and $100 \mu \mathrm{g} / \mathrm{mL}$ of hyperforin.

\subsection{Preincubation of the PMNs with Hyperforin}

After preincubation of the PMNs, but not bacteria, with hyperforin, a similar pattern was seen (Table 2). However, the uptake of non-opsonized E. coli was more efficiently stimulated by $100 \mu \mathrm{g} / \mathrm{mL}$ of hyperforin after preincubation of PMNs than after preincubation of bacteria. Regarding serum-opsonized bacteria, the inhibiting effect was of the same magnitude as that seen after PMN preincubation with hyperforin; the inhibiting effect on the uptake of IgG-opsonized bacteria was less pronounced than after preincubation of the bacteria. Only a slight but significant inhibition was seen with $10 \mu \mathrm{g} / \mathrm{mL}$. 


\subsection{Preincubation of the PMNs and Bacteria and Uptake in the Presence of Hyperforin}

Table 3 shows that preincubation of the PMNs for 30 min and the bacteria for $5 \mathrm{~min}$ followed by uptake in the presence of hyperforin resulted in even more pronounced effects. With $100 \mu \mathrm{g} / \mathrm{mL}$, the uptake of non-opsonized $E$. coli increased almost 50-fold and the uptake of IgG-opsonized $E$. coli increased more than threefold. The uptake of serum-opsonized bacteria, however, was reduced by approximately $40 \%$ with $100 \mu \mathrm{g} / \mathrm{mL}$ of hyperforin.

\subsection{Elimination of Bacteria Breakdown Products from the PMNs}

Table 4 shows the elimination of radiolabeled bacterial breakdown products from the PMNs during the first hour of the post ingestion phase. When the PMNs and bacteria were pretreated with hyperforin, and uptake and elimination took place in its presence $(10 \mu \mathrm{g} / \mathrm{mL})$, the elimination of non-opsonized $E$. coli proceeded normally, while the elimination of IgG-opsonized bacteria was stimulated.

During recent years, it has become clear that despite

Table 1. Uptake of E. coli by human polymorphonuclear neutrophils (PMNs) after pre-incubation of $E$. coli with hyperforin.

\begin{tabular}{ccc}
\hline Hyperforin concentration & Uptake of non-opsonized $E$. coli & Serum-opsonized $E$. coli \\
\hline $1 \mu \mathrm{g} / \mathrm{mL}$ & $107.2+13.0$ & $103.2+3.2$ \\
$10 \mu \mathrm{g} / \mathrm{mL}$ & $112.4+14.1$ & $94.4+4.9$ \\
$100 \mu \mathrm{g} / \mathrm{mL}$ & $178.8+17.7^{* * *}$ & $80.0+4.8^{* *}$ \\
\hline
\end{tabular}

${ }^{\mathrm{a}}$ All values are mean + standard error of measurement $(\mathrm{SEM})$ in percent of control; ${ }^{\mathrm{b}}$ Compared to control: ${ }^{*}=\mathrm{P}<0.05 ;{ }^{* *}=\mathrm{P}<0.01$ and ${ }^{* * *}=\mathrm{P}<0.001$. Done by Student's t-test.

Table 2. Uptake of E. coli by human polymorphonuclear neutrophils (PMNs) after pre-incubation of human polymorphonuclear neutrophils with hyperforin.

\begin{tabular}{cccc}
\hline Hyperforin concentration & Uptake of non-opsonized $E$. coli & Serum-opsonized E. coli & IgG-opsonized E. coli \\
\hline $1 \mu \mathrm{g} / \mathrm{mL}$ & $107.2+6.5$ & $102.1+3.0$ & $105.3+5.6$ \\
$10 \mu \mathrm{g} / \mathrm{mL}$ & $130.7+3.8$ & $97.6+5.3$ & $103.2+9.1^{*}$ \\
$100 \mu \mathrm{g} / \mathrm{mL}$ & $619.4+39.9^{* * *}$ & $75.9+9.1^{* *}$ & $102.0+22.5^{* * *}$
\end{tabular}

${ }^{\mathrm{a}}$ All values are mean + standard error of measurement $(\mathrm{SEM})$ in percent of control; ${ }^{\mathrm{b}}$ Compared to control: ${ }^{*}=\mathrm{P}<0.05 ;{ }^{* *}=\mathrm{P}<0.01$ and ${ }^{* * *}=\mathrm{P}<0.001$. Done by Student's t-test.

Table 3. Uptake of E. coli by human polymorphonuclear neutrophils (PMNs) in presence of hyperforin after pre-incubation of the human polymorphonuclear neutrophils for $30 \mathrm{~min}$ and $E$. coli for $5 \mathrm{~min}$ with hyperforin.

\begin{tabular}{cccc}
\hline Hyperforin concentration & Uptake of non-opsonized E. coli & Serum-opsonized E. coli & IgG-opsonized E. coli \\
\hline $1 \mu \mathrm{g} / \mathrm{mL}$ & $143.1+7.9^{* * *}$ & $97.8+6.6$ & $119.5+7.9^{*}$ \\
$10 \mu \mathrm{g} / \mathrm{mL}$ & $512.9+50.6^{* * *}$ & $93.8+3.1$ & $130.3+6.1^{*}$ \\
$100 \mu \mathrm{g} / \mathrm{mL}$ & $4839.8+379.4^{* * *}$ & $61.1+3.3^{* * *}$ & $325.2+43.0^{* * *}$ \\
\hline
\end{tabular}

${ }^{\mathrm{a}}$ All values are mean + standard error of measurement $(\mathrm{SEM})$ in percent of control; ${ }^{\mathrm{b}}$ Compared to control: ${ }^{*}=\mathrm{P}<0.05 ;{ }^{* *}=\mathrm{P}<0.01$ and ${ }^{* * *}=\mathrm{P}<0.001$. Done by Student's t-test.

Table 4. Elimination of E. coli breakdown products from human polymorphonuclear neutrophils (PMNs) after uptake of $E$. coli in presence of hyperforin $10 \mu \mathrm{g} / \mathrm{mL}$. The human polymorphonuclear neutrophils were pre-incubated for 30 min and E. coli for 5 min with hyperforin before phagocytosis started.

\begin{tabular}{cccc}
\hline & Uptake of non-opsonized $E$. coli & Serum-opsonized $E$. coli & IgG-opsonized E. coli \\
\hline Control & $50.0+3.9$ & $47.2+4.2$ & $48.0+3.9$ \\
Hyperforin & $56.7+5.0$ & $51.9+2.9$ & $63.6+4.1^{*}$ \\
\hline
\end{tabular}

${ }^{\mathrm{a}}$ All values are mean $+\mathrm{SEM}$ expressed as percent radioactivity released during the first 60 min after cessation of uptake; ${ }^{\mathrm{b}} \mathrm{Compared}$ to control: ${ }^{*}=\mathrm{P}<0.05$. Done by Student's t-test. 
the availability of a large number of potent broad-spectrum antimicrobial agents, we are still unable to cure many infections, particularly in immunocompromised patients. In these patients, defective host defense often results in serious microbial infections. In addition to traditional chemotherapy, immunocompromised patients would benefit from agents that stimulate host defense reactions, such as enhancement of phagocyte functions and elimination of bacterial breakdown products from the PMNs, through the development of drugs with socalled immunomodulation effects. The search for such agents has also included substances derived from plants [10,30]. As shown by Delaveau et al. [31], intraperitoneal phagocytosis of $E$. coli in mice was stimulated by a large number of plant extracts. They also tested $H$. perforatum L. but found it to be inactive. Their extraction procedure, however, tended to degrade hyperforin, and hyperforin may not have been completely extracted because of its low water solubility.

The present study showed that hyperforin, as obtained by our procedure, markedly enhanced phagocytosis of non-opsonized $E$. coli. The drug seemed to bind firmly to both bacteria and PMNs, because preincubation followed by washing in both cases enhanced subsequent phagocytosis in the absence of hyperforin. However, the most pronounced stimulation of phagocytosis was seen when hyperforin was present during the uptake phase. In this case, $100 \mu \mathrm{g} / \mathrm{mL}$ of hyperforin promoted uptake approximately twice as efficiently as did $10 \%$ serum and opsonization with IgG. The binding of hyperforin to the bacteria obviously interfered to some extent with the binding of IgG. However, hyperforin binding to the PMNs seemed to affect the Fc receptor only marginally. When hyperforin was present at high concentrations during the uptake of IgG-opsonized bacteria, the slight inhibiting influence on the binding to the PMNs'Fc receptors was therefore outweighed by the phagocytosis enhancement effect of hyperforin per se. Hyperforin therefore seemed to act like an opsonin by itself.

The experiments with serum-opsonized E. coli demonstrated that hyperforin interferes with opsonins other than IgG. This was particularly evident from the experiments where hyperforin was present during phagocytosis (Table 3). In contrast to the stimulating effect seen on the uptake of $\mathrm{IgG}$-opsonized $E$. coli in this setting, the inhibitory effect of hyperforin was potentiated compared with the effect of preincubation of bacteria or PMNs alone. In spite of the inhibitory effect on the uptake of serum-opsonized $E$. coli, hyperforin did not inhibit the intracellular degradation of the bacteria in the PMNs. On the contrary, with IgG-opsonized bacteria, the breakdown of ingested bacteria proceeded more efficiently in the presence of hyperforin. The present in vitro observations on the effect of hyperforin on phagocytosis by PMNs have not yet been confirmed in vivo. Whether this agent also promotes phagocytosis in vivo should be ex- amined. If it does, hyperforin may become a valuable drug for treating infections, particularly in immunocom- promised patients, in spite of its rather narrow antibacte- rial spectrum.

\section{CONCLUSIONS}

1) Hyperforin has the ability to enhance immunity by positive modulation of phagocytosis.

2) Hyperforin has the ability to enhance the breakdown of bacteria ingested by PMNs.

3) Hyperforin is active against Gram-positive Coccaceae (even antibiotic-resistant species), and it is active against some Gram-negative Coccaceae, such as Neisseria $[10]$.

4) Hyperforin has the ability to penetrate the bloodbrain barrier (BBB) and blood-testis barrier (BTB), so it is a valuable antibiotic in cases of meningitis and gonorrhea for patients with AIDS.

5) Hyperforin is active against multiple-antibiotic-resistant Gram-positive organisms [10].

6) Hyperforin is generally important as an antibiotic with immunomodulation properties for immunocompromised persons infected by Gram-positive antibiotic-sensitive and antibiotic-resistant Coccaceae, including methicillin-resistant Staphylococcus aureus (MRSA).

7) Hyperforin molecules bind with serum [10], and it seems they act also as opsonins, which are competing for the same acceptors.

\section{ACKNOWLEDGEMENTS}

The present study was supported by Jupiter Ltd., Norway.

\section{REFERENCES}

[1] Osborn, E.M. (1943) On the occurrence of antibacterial substances in green plants. British Journal of Experimental Pathology, 24, 227-231.

[2] Neuwald, F. and Hagenstrøm, U. (1954) Undersuchungen uber die antibakterelle Wirkung von Hypericum perforatum L. Archiv der Pharmazie, 287, 439-441.

doi:10.1002/ardp.19542870805

[3] Gaind, K.N. and Ganjoo, T.N. (1959) Anti-bacterial principle of Hypericum perforatum Linn. Indian Journal of Pharmaceutical, 21, 172-175.

[4] Jensen, L.B. and Miller, W.A. (1951) Antibiotic from St. John's wort as a food presservative. Chemical Abstracts, 45, 7724 .

[5] Gurevich, A.I., Dobrynin, V.N., Kolosov, M.N., Popravko, S.A., Ryabova, I.D., Chernov, B.K., Derbentseva, N.A., Aizenman, B.E. and Garagulya, A.D. (1971) Hyperforin, an antibiotic from Hypericum perforatum. Antibiotiki Khimioter, 16, 510-513. 
[6] Maksyutina, N.P. and Koget, T.A. (1971) Polyphenols from the grass Hypericum perforatum and the preparation novoimanin. Khimiya Prirodnykh Soedinenii, 7, 363-367.

[7] Derbentseva, N.A. and Rabinovich, A.S. (1968) Isolation, purification, and study of some physicochemical properties of no-voimanin, in Novoimanin Ego Lech. In: Solov'eva, A.I., Ed., Svoistva, USSR, 15-18.

[8] Aizenman, B.E. (1969) Antibiotic preparations from Hypericum perforatum. Mikrobiologicheskiĭ zhurnal, 31, 128-133.

[9] Khosa, R.L. and Bhatia, N. (1982) Antifungal effect of Hypericum perforatum. Journal of the Scientific Research on Plants Medicine, 3, 49-50.

[10] Brondz, I. (1979) Antibiotikumet hyperforin og andre innholdsstoffer i drogen Hypricum perforatum L. Candidatus Pharmaceuticus Thesis, Universitetet i Oslo, Oslo.

[11] Brondz, I., Greibrokk, T. and Aasen, A.J. (1983) n-Alkanes of Hypericum perforatum: A revision. Phytochemistry, 22, 295-296. doi:10.1016/S0031-9422(00)80110-7

[12] Brondz, I., Greibrokk, T., Aasen, A. J. (1982) $n$-1-alkanols of Hypericum perforatum. Journal of Natural Products, 46, 940-941. doi:10.1021/np50030a025

[13] Brondz, I., Greibrokk, T., Groth, P.A. and Aasen, A.J. (1982) The relative stereo chemistry of hyperforin-An antibiotic from Hypericum perforatum L. Tetrahedron Letters, 23, 1299-1300. doi:10.1016/S0040-4039(00)87088-4

[14] Brondz, I., Greibrokk, T., Groth, P. and Aasen, A.J. (1983) The absolute configuration of hyperforin, an Antibiotic from Hypericum perforatum L., based on the crystal structure determination of its $p$-bromobenzoate ester. Acta Chemica Scandinavica, 37A, 263-265. doi:10.3891/acta.chem.scand.37a-0263

[15] Schempp, C.M., Pelz, K., Wittmer, A., Schöpf, E. and Simon, J.C. (1999) Antibacterial activity of hyperforin from St. John's wort, against multiresistant Staphylococcus aureus and gram-positive bacteria. Lancet, 353, 21292132. doi:10.1016/S0140-6736(99)00214-7

[16] In: Budavari, S., Ed., (1989) The Merck Index. 11th Edition, Merck \& Co., Inc., Rahway, New Jersey.

[17] Rückera, G., Mannsa, D., Hartmannb, R., Bonselsa, U. (1995) A C50-Hydroperoxide from Hypericum perforatum. Archives of Pharmacy, 328, 725-730. doi:10.1002/ardp.19953281007

[18] Brondz, I. and Brondz, A. (2011) Suppression of immunity by some pesticides, xenobiotics and industrial chemicals. (In vitro model). Journal of Biophysical Chemistry, 2, 226-232. doi:10.4236/jbpc.2011.23028

[19] Couldwell, D.L. (2001) Invasive menin gococcal disease and HIV coinfection. Communicable Diseases Intelligence Quarterly Report, 25, 279-280.
[20] Gilks, C.F., Brindle, R.J., Otieno, L.S., Simani, P.M., Newnham, R.S. and Bhatt, S.M. (1990) Life-threatening bacteraemia in HIV-1 seropositive adults admitted to hospital in Nairobi, Kenya. Lancet, 336, 545-549. doi:10.1016/0140-6736(90)92096-Z

[21] Bekondi, C., Bernede, C., Passone, N., Minssart, P., Kamalo, C., Mbolidi, D. and Germani, Y. (2006) Primary and opportunistic pathogens associated with menin gitis in adults in Bangui, Central African Republic, in relation to human immune deficiency virus serostatus. International Journal of Infectious Diseases, 10, 387-395. doi:10.1016/j.ijid.2005.07.004

[22] Morla, N., Guibourdenche, M. and Riou, J.Y. (1992) Neisseria spp. and AIDS. Journal of Clinical Microbiology, 30, 2290-2294.

[23] Stephens, D.S., Hajjeh, R.A., Baughman, W.S., Harvey, R.C., Wenger, J.D. and Farley, M.M. (1995) Sporadic meningococcal disease in adults: Results of a 5-year population-based study. Annals of Internal Medicine, 123, 937-940.

[24] Pearson, I.C., Baker, R., Sullivan, A.K., Nelson, M.R. and Gazzard, B.G. (2001) Meningococcal infection in patients with the human immunodeficiency virus and acquired immunodeficiency syndrome. International Journal of STD \& AIDS, 12, 410-411. doi:10.1258/0956462011923237

[25] Bøyum, A. (1968) Isolation of leucocytes from human blood-further observations (Paper II). Scandinavian Journal of Clinical \& Laboratory Investigation, 97, 31-50.

[26] Bøyum, A. (1968) Isolation of mononclear cells and granulocytes from human blood (Paper IV). Scandinavian Journal of Clinical \& Laboratory Investigation, 97, 77-89.

[27] Bøyum, A. (1976) Isolation of lymphocytes, granulocytes and macrophages. Scandinavian Journal of Immunology, 5, 9-15. doi:10.1111/j.1365-3083.1976.tb03851.x

[28] Benacerraf, B., Sebestyen, M.M. and Schlossman, S. (1959) A quantitative study of the kinetics of blood clearance of ${ }^{32} \mathrm{P}$-labeled Escherichia coli and staphy lococci by the reticuloendothelial system. Journal of Experimental Medicine, 110, 27-48. doi:10.1084/jem.110.1.27

[29] Oyama, V. L. and Eagle, H. (1956) Measurement of cell growth in tissue culture with a phenol reagent (FolinCiocalteau). Proceedings of the Society for Experimental Biology and Medicine, 91, 305-307.

[30] Brondz, I. (1987) Fourth International Conference on chemistry and biotechnology of biological active natural products. Proceedings of the Fourth International Conference, Budapest, 10-14 August 1987, 119.

[31] Delaveau, P., Lallouette, P. and Tessier, A.M. (1980) Stimulation of the phagocytic activity of the r.e.s. by plant extracts. Planta Medica, 40, 49-54. doi:10.1055/s-2008-1074941 